\title{
Metadiscourse in Students' Academic Writing: Case Study of Umaru Musa Yar'adua University and Al-Qalam University Katsina
}

\author{
Hamisu Hamisu Haruna ${ }^{1}$, Bello Ibrahim ${ }^{1}$, Musa Haruna ${ }^{1}$, Bashir Ibrahim $^{2} \&$ Kamariah Yunus ${ }^{2}$ \\ ${ }^{1}$ Al-Qalam University Katsina, IBB Way off Dutsin-ma Road Katsina State of Nigeria, Nigeria \\ ${ }^{2}$ Universiti Sultan Zainal Abidin, Gong Badak Campus, 21300, Kuala Nerus, Terengganu, Malaysia \\ Correspondence: Kamariah Yunus, Faculty of Languages and Communication, Universiti Sultan Zainal Abidin, \\ Gong Badak Campus, 21300, Kuala Nerus, Terengganu, Malaysia. E-mail: kamariah@unisza.edu.my
}

Received: May 23, 2018 Accepted: June 20, 2018 Online Published: November 27, 2018

doi:10.5539/ijel.v8n7p83 URL: https://doi.org/10.5539/ijel.v8n7p83

\begin{abstract}
Studies on writing, thus, become crucial because when students make the transition from Secondary School to a Tertiary Institution, they encounter many challenges. One of them is the writing of B.A projects. Most of these undergraduate students both in L1 (English as a first language) and L2 (English as a second language) still find it difficult to argue, discuss or evaluate competently as well as persuasively in English essay writing. The present study aimed at exploring metadiscoursal choice and its influence on the success of students' academic writing. The study was conducted within the framework of Appraisal Theory. The data was randomly generated from the written essays by thirty selected Level 400 students both from Umaru Musa Yar'adua University and Al-Qalam University Katsina. Also, the data was descriptively alaysed and presented. It was discovered that six (6) of the essays do not contain the relevant elements for this study, thus excluded from the analysis. To achieve the main objective of this study, the first six categories of the most successful essays and the least successful ones were taken for in-depth analysis. They were analysed paragraph by paragraph and then each interactional metadiscourse element was separately discussed as a whole. The findings showed that many of the students were not exposed to these elements, thus, they write academic essay the way they speak. It is against these findings that the present study unravels that embedding the teaching of metadiscourse in cumulative learning practices could consequently empower students to develop both linguistically and intellectually.
\end{abstract}

Keywords: metadiscourse markers, interactional metadiscourse, academic writing, students' writing

\section{Introduction}

The ever-growing concern about the falling standard of English by examining bodies and university lecturers/researchers in Nigerian Universities is not unusual, since similar anxiety has, for years, been voiced out by lecturers and teachers about students' poor academic performance. This is because writing is the medium through which students are assessed academically (Kamal, 2004). This fact becomes more serious because English language is considered to be the international language and the universal language of communication, as its proficiency becomes an essential aspect for those aspiring for academic success. In particular, effective writing skills are paramount for success in higher learning, work and society (Grabe \& Kaplan, 1996). This form of writing is particularly problematic for non-native speakers of English, who are often linguistically and rhetorically inexperienced when it comes to writing essays in English (Mohamed \& Bahari, 2017; Thompson, 2001). This is because many researchers come to conclusion that students at university often perform poorly in text generation, not because they do not have the content, but because their mode of cognitive function is weak.

This fact makes many scholars to emphasise that, developing the skill of successful writing involves, among other things, an awareness of audience in academic writing and the ability to exploit this awareness in written text (Grabe \& Kaplan; 1996; Thompson, 2001; Swales \& Feak, 2004). However, others focus on the correlation between students' awareness of audience and the quality of their writing (Golden, 1980, in Shiyuan 2016). It is this sense of audience, possessed by a good writer, using persuasive language is termed "metadiscourse" (Hyland, 2004).

Mahammed and Rawian (2018) posit that the pressing need for effective writing skills, thus, has led to an increasing interest in the study of interaction in written texts in the previous decades. This is because cases often 
arise of university students' essays failing to fulfill certain requirements. This is largely caused by the fact that, metadiscourse, which establishes ways of organising a message and facilitating the communication quality in the text, is not only quite a new concept in the area of text analysis but also a degree of opacity that leads to the paucity of linguistic dexterity and research on its important use in essay writings (Mohamed \& Rashid, 2017). Drawing on earlier classifications of writer and reader interactions (Kopple, 1985), Hyland (2005) created one of the most complete models for the study of interaction in written texts: the metadiscourse model. Thus, prompted by the fact that metadiscourse, a rhetorical domain that regulates the communicative function of language, can be used to convey a message and create solidarity between a writer and a reader in academic writings. This paper attempts an analysis of metadiscoursal choice to examine the degree to which the final year students of Umaru Musa Yar'adua University and Al-Qalam Univesity Katsina produce the persuasive efficacy of metadiscourse markers in their essays. The main objective of the research is to discover how the choice of hedges, boosters, attitude markers, engagement markers and self-mentions affect students' marks scored in their essays (Mahammed \& Rawian 2018).

\section{Proliferations}

\subsection{Studies on Metadiscourse}

Although metadiscourse is relatively a new concept, it has generated a lot of research in recent years. There have been numerous studies of various aspects of metadiscourse (e.g., hedging, imperatives, self-mention) in a range of genres. A range of recent studies in text analysis have been devoted to the presence and functional role of metadiscourse markers in various genres including science popularisations (Crismore \& Farnsworth, 1990, p.58), textbooks (Crismore, 1983, 1984; Hyland, 1999; Noorian \& Biria, 2017), students writing (Intaraprawat \& Steffensen, 1995), and research articles (Hyland, 1998, 1999; Abdi, 2002; Therova, 2018). Metadiscourse has also been used to examine rhetorical differences in the texts written by different first language groups and those produced by ESL and native writers. In his comparative study of the use of metadiscourse between introductory textbooks for tertiary students and research articles, Chen, Song, \& Heo, (2018) findings showed that, although both types of texts exhibited a greater use of textual metadiscourse, there was an increase in the use of interpersonal metadiscourse in the research articles. This is not surprising as research articles, being persuasive in nature, would employ a greater use of interpersonal metadiscourse. Apart from this, Hyland (2004) examined the metadiscourse use in 240 Masters and Doctoral dissertations of six disciplines; Computer science, Electronic Engineering, Business Studies, Biology, Applied Linguistics, and Public Administration. The results indicated that the use of metadiscourse is an important rhetorical device in the academic genre particularly in postgraduate dissertations where the students used slightly more interactive than interactional forms.

Besides postgraduate dissertations, metadiscourse has also been examined in undergraduate academic writings. Chen and Flowerdew (2018) for instance, compared the use of metadiscourse in good and poor undergraduate essays and found that good essays employed more interactional metadiscourse while the weak essays exhibited more of the use of interactive. Furthermore, good essays were found to have more and a wider range of metadiscourse forms. Ho and $\mathrm{Li}$ (2018) hold that this led them to conclude that, metadiscourse use has a bearing on the quality of the essays. Despite these studies, there is still dearth of in-depth study which explores interactional metadiscourse choice especially in the final year undergraduate students of B.A English. This paper, therefore, highlights the need for the present study and proposes to extend the current research by applying Hyland's (2005, pp. 75-100) model of interactional metadiscoursal choice on the writings of the students' essays.

The study is therefore significant in that, it focuses on exploring interpersonal components in the students' writing from a perspective of writer and reader interaction. This is because the correlation between academic success and exploitation of the interpersonal aspect of academic argument and persuasion has been significantly under-researched (Intaraprawat \& Steffensen, 1995). Hence, the research will contribute in extending the frontiers of linguistic appreciation through better understanding of meanings and appropriate usages in writing especially in the areas of Applied Linguistics, Discourse Analysis, English for Academic Purposes, English for Specific Purposes and Advanced Composition. This claim is supported by Hyland (2005) who holds that interactional metadiscourse elements, in particular, play a crucial role in contributing new knowledge and "making academic claims".

\subsection{The Concept of Metadiscourse}

As a linguistic construct, metadiscourse has received much attention in Applied Linguistics over the past few decades, particularly in the fields of Composition, Academic writing and Discourse Analysis. For this reason, writing scholars have been fascinated by the role of metadiscourse in writing and each has defined metadiscourse in their own way. However, despite the proliferation of definitions, it has been lamented that metadiscourse "has 
always been something of a fuzzy term" (Hyland, 2005, p. 16). This is especially true considering its various definitions which are usually vague or elusive, such as "writing about writing" (Williams, 1985, p. 226), and "discourse about discourse" (Kopple, 1985, p. 83). The fuzziness of this term, as observes, can be partly attributed to the "heterogeneity of the features of spoken and written discourse which can signal the dimensions of context that metadiscourse refers to, as remarked by Swales (1990, p. 188) that while the concept is easy to accept in principle, it is more difficult to establish its boundaries:

The word 'metadiscourse' may have a reassuringly objective, 'scientific' ring, but its usage suggests boundaries of definition no more firmly drawn than those of, say, 'rhetoric' or 'style'. One reader may perceive a clear stylistic intention in something which another reader dismisses as a commonplace, 'automatized' use of language. (Nash, 1992, p. 100)

Although the arguments surrounding metadiscourse have not been resolved, researchers, notwithstanding, have made attempts at the phenomenon more systematically by drawing upon various theoretical perspectives. For Kopple (1985), metadiscourse functions as a linguistic device in writings which indicates the writer's presence but does not add any additional propositional information. In a similar vein, Overbeck (2017) explicates the roles of the term in its interactive value as they see metadiscourse as "a writing device that helps writers to structure their writing discourse and display their stance towards the text or the reader." More recently, Williams (2007, p. 65) comments that metadiscourse is the language that refers "not to the substance of your ideas, but to yourself, your reader, or your writing."

Similarly, the concept of metadiscourse is based on a view of writing (and speaking) as a social and communicative interaction, offering a means of understanding the ways we project ourselves into our texts to manage our communicative intentions. Metadiscourse is, therefore, an important concept that seems to offer a motivation for collecting, under one heading, the range of devices writers use to explicitly organise their text, engage readers and signal their attitudes to both their material and their audience. Hyland (1998, p. 80) opines:

Hence, metadiscourse is an umbrella term to include a heterogeneous array of cohesive and interpersonal features which help relate a text to its context by assisting readers to connect, organise, and interpret material in a way preferred by the writer and with regard to the understandings and values of a particular discourse community.

Crucial to metadiscourse, according to Hight and Harindranath (2017) as cited in Hyland (2005), is the writer's conscious engagement with the reader as creating a convincing reader environment that involves deploying metadiscoursal resources so that the final text is co-produced by the author and the members of the audience to which it is directed:

Metadiscourse reveals the writer's awareness of the reader and his or her need for elaboration, clarification, guidance and interaction. In expressing an awareness of the text, the writer also makes the reader aware of it, and this only happens when he or she has a clear reader-oriented reason for doing so (p. 17).

The discussions above reveal that every writer interacts with readers in their texts. The interaction may be encoded explicitly or implicitly by some linguistic expressions called metadiscourse (Latif, Hadi, Yusof, \& Rahman, 2018).

Sclafani, Bektik, Wilkins; Chen \& Flowerdew; Chen, Song \& Heo; Therov; Ho \& Li $(2017 ; 2018)$ are of the view that Metadiscourse can therefore be regarded as a way of understanding how academic writers express their interpersonal understandings, how they shape their propositions to create convincing, coherent discourse in particular social and institutional contexts (Kız1l, 2017). An orientation to the reader is crucial in securing rhetorical objectives in research writing as writers have to anticipate and respond to the potential negation of their arguments. Moreover, Sclafani, et.al adds that Metadiscourse is fold into two useful terms, interactive and interactional resources, and are elaborated below.

Interactive resources allow the writer to manage the information flow to explicitly establish his or her preferred interpretations. They are concerned with ways of organising discourse to anticipate readers' knowledge and reflect the writer's assessment of what needs to be made explicit to constrain and guide what can be recovered from the text. These resources include the following:

1) Transitions comprise an array of devices, mainly conjunctions, used to mark additive, contrastive, and consequential steps in the discourse, as opposed to the external world.

2) Frame markers are references to text boundaries or elements of schematic text structure, including items used to sequence, to label text stages, to announce discourse goals, and to indicate topic shifts. 
3) Endophoric markers make additional material salient and available to the reader in recovering the writer's intentions by referring to other parts of the text.

4) Evidentials indicate the source of textual information which originates outside the current text.

5) Code glosses signal the restatement of ideational information.

Interactional resources focus on the participants of the interaction and seek to display the writer's personal and a tenor consistent with the norms of the disciplinary community. Metadiscourse here concerns the writer's efforts to control the level of personality in a text and establish a suitable relationship to his or her data, arguments, and audience, marking the degree of intimacy, the expression of attitude, the communication of commitments, and the extent of reader involvement. They include:

1) Hedges mark the writer's reluctance to present propositional information categorically.

2) Boosters express certainty and emphasise the force of propositions.

3) Attitude markers express the writer's appraisal of propositional information, conveying surprise obligation, agreement, importance, and so on.

4) Engagement markers explicitly address readers, either by selectively focusing their attention or by including them as participants in the text through second person pronouns, imperatives, question forms and asides (Hyland, 2001a).

5) Self-mentions suggest the extent of author presence in terms of first person pronouns and possessives case.

\section{Methodology}

The study was carried out by administering a test to the subjects of the research (Level 400 students of UMYU and AUK). They were given the same topic and asked to write an essay of not more than a page for publication in the University Bulletin, on the topic: "The Collapse of Education is the Collapse of the Nation". For the essays to be analysed, descriptive research design as suggested by Tavakoli, 2012. A total of one hundred and six (106) students served as the population of the research and by adopting Krejie and Morgan's (1970) equal and fair chance of all the subjects opportunity of being selected in the sample, the researchers used simple random sampling and selected thirty (30) subjects to form the sample size. After the test, with the help of research assistants, the essays underwent two levels of analysis. The first was made by the veteran English Language teachers who used the five point web criteria of scoring contained in the International English Language Testing System (IELTS) which are: Communication Quality, Organisation, Argumentation, Linguistic Accuracy and Linguistic Appropriacy; while the second was conducted as shown in the analysis and discussions.

\section{Data Analysis}

As mentioned earlier, the corpus was analysed based on the five classifications of interactional metadiscourse elements, proposed by Hyland (2005), as set out in the following table:

Table 1. Interactional model of metadiscourse (Hyland, 2005)

\begin{tabular}{lll}
\hline Category: Interactional Metadiscourse & Function: Involve reader in the text. & Example: Resources \\
\hline Hedges & withhold commitment and open dialogue & might; perhaps; possible; about \\
Boosters & emphasize certainty and close dialogue & in fact; definitely; it is clear that \\
Attitude markers & express writers' attitude to proposition & unfortunately; I agree; surprisingly \\
Self-mentions & explicit reference to author(s) & I; we; my; me; our \\
Engagement markers & explicitly build relationship with reader & consider; note; you can see that \\
\hline
\end{tabular}

The main essence of the analysis was to indicate the possible deployment of these elements in the essays. Hence, they were photocopied four times, making the sum total of one hundred and twenty copies (120). Each of the thirty set of essays was given to each of the four experienced teachers of English language from the two Universities selected for marking and evaluation. The researchers used simple percentage table to classify the frequency of interactional metadiscourse elements in the respondents' essays.

\subsection{Result Findings}

After the data coding was completed, the number of clauses for the thirty essays totaled to five hundred and eighty four (584). Based on the presentation and analysis of the data obtained, virtually all the forms of interactional metadiscoursal elements were found in the essays with varying degree of frequency. Thus, of the three hundred and seventy (370) markers found in the twenty four (24) analysed essays, engagement markers 
occurred one hundred and nine (109) times which have the highest percentage of instances with $18.7 \%$ discovered. This is followed by hedges occurring ninety eight (98) times which represents $16.8 \%$. Then, self-mentions that occurred seventy five (75) times representing $12.8 \%$. in addition, boosters appeared sixty six (66) times accounting for $11.3 \%$. Finally, attitude markers which has the least frequency of twenty two (22) times in the overall texts, account for $3.8 \%$.

Table 2. Total number of the elements that appeared in the texts

\begin{tabular}{lll}
\hline Items & Raw Numbers & Percentages \\
\hline Hedges & 98 & $16.8 \%$ \\
Boosters & 66 & $11.3 \%$ \\
Attitude Markers & 22 & $3.8 \%$ \\
Engagement Markers & 109 & $18.7 \%$ \\
Self-Mention & 75 & $12.8 \%$ \\
Total Markers & $\mathbf{3 7 0}$ & $\mathbf{6 3 . 4 \%}$ \\
\hline
\end{tabular}

The first six categories of the most successful essays and the least successful ones were taken for in-depth analysis. The texts were analysed paragraph by paragraph and through this intra-paragraph examination, each interactional metadiscourse element was separately discussed.as a whole. For the research validity purpose, all the clauses extracted from the students' essays were written directly from the original sources without alteration.

\subsection{Findings and Discussions}

Based on the presentation and analysis of the data, this study showed that the interactional metadiscoursal choices that the final year students of UMYU and AUK made affected how their writing was perceived and scored. Thus, even if the students did not realise that they were making incorrect metadiscoursal choices, because of their limited knowledge, these features had negative effects on the reception of their essays.

For example, the findings from this study revealed a significant difference between the most successful students and the least successful ones. The former, for instance, interacted more with their imagined recipients (examiners) in a more academic way and, where necessary, open room for negotiation by way of weakening their claims (through hedges), sometimes, occasionally expressing their certainty on their claims (through boosters), and more often engage their readers as discourse participants (through engagement markers). However, they minimised their explicit presence in the essays and, thus, were more successful. The results of this study are in line with those obtained by Intaraprawat, P., and Steffensen, M. S. (1995) who compared and contrasted between good and poor ESL Essays in the use of metadiscourse.

In contrast, the latter boosted their claims and closed down alternatives awkwardly by using words like true, clear, without any doubt, always, never etc, without respecting proper social relationships with their teachers and creating too high of the degree of authority as supported by Noorian \& Biria, (2017). Similarly, they write in the way they speak through the explicit use of pronouns " $\Gamma$ " and "we" that create informal and direct argument which made them as "opinion holders" or "arguers" (which is considered as relatively high-risking discourse functions). This, in addition to wrong spellings and collocations, put much strain on the examiners and therefore affected their marks negatively. For example, some clauses made by the least successful essayists portrayed such instance:

$i$. At this juncture let me discourse (discuss) about teaching profession in Nigeria, whereby almost sixty percent to seventy percent are having severe headech (headache). (Text 6)

ii. A weeked (weak) teacher can provide a weeked (weak) society. (Text 6)

iii. In a not shell (nutshell), corruption is not a certain thing that we have to be proud with (of). (Text 3)

As can be seen from the above examples, majority of the least successful essays have in them incidence of grammatically deviant sentences characterised by punctuations and mechanical errors in tense, concord, wrong collocations and even spellings. These findings are similar to the findings of Lee (2010) who also indicated that interpersonal features used by her ESL writers created a voice that was too conversational.

\subsection{Summary of the Findings}

In the light of the above, the following are the researchers' findings as follows:

1) While some students made a good choice of interactional markers in their essays and, by implication, positively affected the high marks scored, it was found that many of them were not exposed to these 
elements which directly affected the wrong choice of the elements.

2) It was discovered that the wrong choice of these elements has a link in the way they write the way they speak (in informal context).

3) The paper, finally, unravels that embedding the teaching of metadiscourse in cumulative learning practices could consequently empower students' right choice of the elements.

\section{Conclusion and Recommendations}

As broached, this paper was undertaken to examine the influence of interactional metadiscoursal choice in students' essays. This followed the realisation that, in the past writing was taught by either imitating sample works from experts or by focusing on elements and grammatical points, and the role of metadiscourse features was neglected. The textual analysis was made by the researchers in which the elements were described, interpreted and analysed. Based on the findings of this study it can be claimed that university students will write better and more successfully if they are given formal teaching about metadiscourse.

\section{References}

Abdi, R. (2002). Interpersonal Metadiscourse: An Indicator of Interaction and Identity. Discourse Studies, 4(2), 139-145. https://doi.org/10.1177/14614456020040020101

Bektik, D. (2017). Learning Analytics for Academic Writing through Automatic Identification of Meta-discourse (Doctoral dissertation, The Open University).

Chen, C., Song, M., \& Heo, G. E. (2018). A scalable and adaptive method for finding semantically equivalent cue words of uncertainty. Journal of Informetrics, 12(1), 158-180. https://doi.org/10.1016/j.joi.2017.12.004

Chen, M., \& Flowerdew, J. (2018). Introducing data-driven learning to $\mathrm{PhD}$ students for research writing purposes: A territory-wide project in Hong Kong. English for Specific Purposes, 50, 97-112. https://doi.org/10.1016/j.esp.2017.11.004

Crismore, A., \& Farnsworth, R. (1990). Metadiscourse in Popular and Professional Science Discourse. In W. Nash (Ed.), The Writing Scholar: Studies in Academic Discourse. Newbury Park, CA: Sage.

Crismore, A., Markkanen, R., \& Steffensen, M. S. (1993). Metadiscourse in persuasive writing: A study of texts written by American and Finnish university students. Written Communication, 10(1), 39-71. https://doi.org/10.1177/0741088393010001002

Faghih, E., \& Rahimpour, S. (2009). Contrastive Rhetoric of English and Persian Written Texts: Metadiscourse in Applied Linguistics Research Articles. Rice Working Papers in Linguistics, 1, 92-107.

Grabe, W., \& Kaplan, R. B. (1996). Theory and practice of writing: An applied linguistic perspective. New York: Longman.

Hight, C., \& Harindranath, R. (Eds.). (2017). Studying Digital Media Audiences: Perspectives from Australasia (Vol. 35). Taylor \& Francis. https://doi.org/10.4324/9781315402062

Ho, V., \& Li, C. (2018). The use of metadiscourse and persuasion: An analysis of first year university students' timed argumentative essays. Journal of English for Academic Purposes, 33, 53-68. https://doi.org/10.1016/j.jeap.2018.02.001

Hyland, K. (1998). Boosting, Hedging and the Negotiation of Academic Knowledge. Text, 18, 349-382. https://doi.org/10.1515/text.1.1998.18.3.349

Hyland, K. (2004). Disciplinary Interactions: Metadiscourse in L2 Postgraduate Writing. Journal of Second Language Writing, 13, 133-151. https://doi.org/10.1016/j.jslw.2004.02.001

Hyland, K. (2005). Metadiscourse: Exploring Interaction in Writing. London: Continuum.

Hyland, K., \& Tse, P. (2004). Metadiscourse in Academic Writing: A Reappraisal. Applied Linguistics, 25(2), 156-177. https://doi.org/10.1093/applin/25.2.156

Intaraprawat, P., \& Steffensen, M. S. (1995). The Use of Metadiscourse in Good and Poor ESL Essays. Journal of Second Language Writing, 4(3), 253-272. https://doi.org/10.1016/1060-3743(95)90012-8

Kamal, A. (2004). Writing Academic English in an ESL Situation: A Case Study of Students of Bayero University, Kano. Unpublished PhD Thesis, Bayero University, Kano.

Kızıl, A. Ş. (2017). Spoken corpora and corpus-informed language pedagogy: Implications arising from research.

Kızıl, A. Ş. (2017). The use of metadiscourse in spoken interlanguage of EFL learners: A contrastive analysis. 
Latif, M. A. N. A., Hadi, A. Z. S. A., Yusof, S., \& Rahman, M. H. A. (2018). Al-Khabar Language Alphabet in Two Ways Dialogue in Al-Qur'an) (Laras Bahasa Al-Khabar Dalam Ayat-Ayat Dialog Dua Hala Al-Qur'an). Malaysian Journal for Islamic Studies, 2(1), 11-24.

Mahammed, A., \& Rawian, R. M. (2018). English Learning Motivation of First-Year Students in Universiti Sultan Zainal Abidin (UniSZA). ASIAN TEFL: Journal of Language Teaching and Applied Linguistics, $1(1)$.

Mauranen, A. (1993). Contrastive ESP Rhetoric: Metatext in Finnish English Economics Texts. English for Specific Purposes, 12, 3-22. https://doi.org/10.1016/0889-4906(93)90024-I

Mohamed, A. F., \& Rashid, R. A. (2017). The metadiscourse markers in good undergraduate writers' essays corpus. International Journal of English Linguistics, 7(6), 213-220. https://doi.org/10.5539/ijel.v7n6p213

Mohamed, M., \& Bahari, A. A. (2016). ESL instructors and learners' views on the use of Dropbox as a sharing tool in writing lessons. Journal of Nusantara Studies, 1(2), 1-10. https://doi.org/10.24200/jonus.volliss2pp1-10

Noorian, M., \& Biria, R. (2017). Interpersonal metadiscourse in persuasive journalism: A study of texts by American and Iranian EFL columnists. Journal of Modern Languages, 20(1), 64-79.

Overbeck, A. (2017). Orality and Literacy of Online Communication. Manual of Romance Languages in the Media, 23, 176. https://doi.org/10.1515/9783110314755-010

Sclafani, J. (2017). Talking Donald Trump: A Sociolinguistic Study of Style, Metadiscourse, and Political Identity. Routledge. https://doi.org/10.4324/9781315276885

Swales, J. M. (1990). Genre Analysis: English in Academic and Research Settings. Glasgow: Cambridge University Press.

Swales, M. J., \& Feak, C. B. (2012). Academic Writing for Undergraduate Students: Essential Skills and Tasks. Machingan. Retrieved from http://www.umich.edu/titleDetailDesc.do?

Therova, D. (2018). What difference does one academic year make? Features and development of international foundation students' academic lexis in assessed writing at a UK university (Doctoral dissertation, The Open University).

Thompson, G. (2001). Interaction in Academic Writing: Learning to Argue with the Reader. Applied Linguistics, 22(1), 58-78. https://doi.org/10.1093/applin/22.1.58

Vande-Kopple, W. J. (1985). Some Explanatory Discourse on Metadiscourse. College Composition and Communication, 36, 82-93. https://doi.org/10.2307/357609

Wilkins, E. M. (2018). Exploring change: oral metadiscourse of advanced learners of Russian in extended study abroad (Doctoral dissertation).

\section{Appendix A}

Table 1. Total number of the elements occurred in the individual texts

\begin{tabular}{|c|c|c|c|c|c|c|}
\hline Text(s) & Clauses & Hedges & Boosters & Attitude markers & $\begin{array}{l}\text { Engagement } \\
\text { markers }\end{array}$ & Self-mentions \\
\hline Text 1 & 17 & $2(11.8 \%)$ & $1(5.1 \%)$ & $1(5.1 \%)$ & $3(17.6 \%)$ & $1(5.1 \%)$ \\
\hline Text 2 & 29 & $2(6.9 \%)$ & $2(6.9 \%)$ & $0(0 \%)$ & $5(20.7 \%)$ & $0(0 \%)$ \\
\hline Text 3 & 23 & $3(13.0 \%)$ & $4(17.4 \%)$ & $0(0 \%)$ & $4(17.4 \%)$ & $8(34.8 \%)$ \\
\hline Text 4 & 15 & $2(13.3 \%)$ & $1(6.7 \%)$ & $3(20 \%)$ & $1(6.7 \%)$ & $0(0 \%)$ \\
\hline Text 5 & 13 & $2(15.4 \%)$ & $3(23.1 \%)$ & $0(0 \%)$ & $3(23.1 \%)$ & $3(23.1 \%)$ \\
\hline Text 6 & 25 & $3(12 \%)$ & $2(8 \%)$ & $0(0 \%)$ & $5(20 \%)$ & $2(8 \%)$ \\
\hline Text 7 & 24 & $5(20.8 \%)$ & $3(12.5 \%)$ & $1(4.2 \%)$ & $2(8.3 \%)$ & $5(20.8 \%)$ \\
\hline Text 8 & 21 & $5(23.8 \%)$ & $4(19.0 \%)$ & $0(0 \%)$ & $10(47.6 \%)$ & $4(19.0 \%)$ \\
\hline Text 9 & 22 & $11(50 \%)$ & $2(9.1 \%)$ & $2(9.1 \%)$ & $4(18.2 \%)$ & $1(4.5 \%)$ \\
\hline Text 10 & 20 & $4(20 \%)$ & $8(40 \%)$ & $2(10 \%)$ & $6(30 \%)$ & $0(0 \%)$ \\
\hline Text 11 & 13 & $6(46.2 \%)$ & $1(7.7 \%)$ & $0(0 \%)$ & $1(7.7 \%)$ & $1(7.7 \%)$ \\
\hline Text 12 & 26 & $5(19.2 \%)$ & $1(3.8 \%)$ & $2(7.7 \%)$ & $0(0 \%)$ & $4(15.4 \%)$ \\
\hline Text 13 & 16 & $4(25 \% 0$ & $2(12.5 \%)$ & $0(0 \%)$ & $0(0 \%)$ & $0(0 \%)$ \\
\hline Text 14 & 30 & $5(16.7 \%)$ & $1(3.3 \%)$ & $1(3.3 \%)$ & $10(33.3 \%)$ & $6(20 \%)$ \\
\hline Text 15 & 19 & $5(26.3 \%)$ & $2(10.5 \%)$ & $1(5.3 \%)$ & $7(36.8 \%)$ & $0(0 \%)$ \\
\hline Text 16 & 18 & $1(5.6 \%)$ & $0(0 \%)$ & $1(5.6 \%)$ & $0(0 \%)$ & $3(16.7 \%)$ \\
\hline Text 17 & 16 & $3(18.8 \%)$ & $4(25 \%)$ & $1(6.3 \%)$ & $2(12.5 \%)$ & $0(0 \%)$ \\
\hline
\end{tabular}




\begin{tabular}{lllllll}
\hline Text 18 & 16 & $3(18.8 \%)$ & $2(12.5 \%)$ & $0(0 \%)$ & $2(12.5 \%)$ & $0(0 \%)$ \\
Text 19 & 30 & $2(6.7 \%)$ & $2(6.7 \%)$ & $1(3.3 \%)$ & $0(0 \%)$ & $3(10 \%)$ \\
Text 20 & 18 & $1(5.6 \%)$ & $1(5.6 \%)$ & $1(5.6 \%)$ & $1(5.6 \%)$ & $1(11.1 \%)$ \\
Text 21 & 34 & $1(2.9 \%)$ & $2(5.9 \%)$ & $0(0 \%)$ & $3(8.8 \%)$ & $6(17.5 \%)$ \\
Text 22 & 29 & $2(6.9 \%)$ & $4(13.8 \%)$ & $2(6.9 \%)$ & $12(41.4 \%)$ & $3(10.4 \%)$ \\
Text 23 & 37 & $10(27.0 \%)$ & $3(8.1 \%)$ & $0(0 \%)$ & $8(21.6 \%)$ & $12(32.4 \%)$ \\
Text 24 & 30 & $2(6.7 \%)$ & $3(10 \%)$ & $1(3.3 \%)$ & $8(26.7 \%)$ & $1(3.3 \%)$ \\
\hline
\end{tabular}

Table 2. Summary of scores for all the essays by examiners

\begin{tabular}{|c|c|c|c|c|c|c|}
\hline Text & $\begin{array}{l}\text { Communication } \\
\text { Quality }\end{array}$ & Organisation & Argumentation & $\begin{array}{l}\text { Linguistic } \\
\text { Accuracy }\end{array}$ & $\begin{array}{l}\text { Linguistic } \\
\text { Appropriacy }\end{array}$ & Total Scores \\
\hline \multirow[t]{4}{*}{ Text 1} & $02^{1 / 2}$ & $02 \frac{1}{2}$ & 03 & 02 & 03 & 13 \\
\hline & 01 & 02 & 01 & 02 & 02 & 08 \\
\hline & 03 & 03 & 02 & 03 & 02 & 13 \\
\hline & 02 & 01 & 01 & 02 & 02 & 08 \\
\hline Total & $08^{1} / 2$ & $091 / 2$ & 07 & 09 & 09 & 43 \\
\hline \multirow[t]{4}{*}{ Text 2} & $02^{1 / 2}$ & 02 & 02 & $02^{1 / 2}$ & 03 & 12 \\
\hline & 04 & 02 & 04 & 03 & 03 & 16 \\
\hline & 04 & 04 & 04 & 04 & 02 & 18 \\
\hline & 03 & 02 & 02 & 02 & 01 & 10 \\
\hline Total & $13 \frac{1}{2}$ & 10 & 12 & $11^{1 / 2}$ & 09 & 56 \\
\hline \multirow{4}{*}{ Text 3} & 00 & 01 & 02 & 02 & 02 & 07 \\
\hline & 02 & 01 & 01 & 02 & 01 & 07 \\
\hline & 03 & 03 & 02 & 01 & 01 & 10 \\
\hline & 02 & 01 & 01 & 01 & $01 \frac{1}{2}$ & $06^{1 / 2}$ \\
\hline Total & 07 & 06 & 06 & 06 & $051 / 2$ & $301 / 2$ \\
\hline \multirow[t]{4}{*}{ Text 4} & $01 \frac{1}{2}$ & 02 & 01 & $02^{1 / 2}$ & $02 \frac{1}{2}$ & 10 \\
\hline & 04 & 04 & 03 & 05 & 03 & 19 \\
\hline & 04 & 04 & 04 & 03 & 03 & 18 \\
\hline & 02 & 02 & 02 & 02 & 01 & 09 \\
\hline Total & $11 \frac{1}{2}$ & 12 & 10 & $12^{1 / 2}$ & $09^{1 / 2}$ & $551 / 2$ \\
\hline \multirow[t]{4}{*}{ Text 5} & 02 & $01 \frac{1}{2}$ & 02 & 02 & $01^{1 / 2}$ & 09 \\
\hline & 02 & 02 & 02 & 01 & 01 & 08 \\
\hline & 04 & 03 & 03 & 02 & 02 & 14 \\
\hline & 02 & 01 & 02 & 01 & 02 & 08 \\
\hline Total & 10 & $071 / 2$ & 09 & 06 & $06^{1 / 2}$ & 39 \\
\hline \multirow[t]{4}{*}{ Text 6} & $02^{1 / 2}$ & $2 \frac{1}{2}$ & $02^{1 / 2}$ & 02 & $02^{1 / 2}$ & 12 \\
\hline & 02 & 02 & 02 & 01 & 01 & 08 \\
\hline & 02 & 03 & 01 & 02 & 02 & 10 \\
\hline & 02 & 03 & 02 & 01 & 01 & 09 \\
\hline Total & $08^{1 / 2}$ & $10^{1 / 2}$ & $071 / 2$ & 06 & $06^{1 / 2}$ & $381 / 2$ \\
\hline \multirow[t]{4}{*}{ Text 7} & 02 & 02 & 02 & $02^{1 / 2}$ & $02^{1 / 2}$ & 11 \\
\hline & 02 & 03 & 02 & 02 & 01 & 10 \\
\hline & 03 & 03 & 02 & 02 & 02 & 12 \\
\hline & 03 & 02 & 02 & 01 & 01 & 09 \\
\hline Total & 10 & 10 & 08 & $071 / 2$ & $06^{1} 1 / 2$ & 42 \\
\hline \multirow[t]{4}{*}{ Text 8} & 03 & 03 & 03 & 03 & 03 & 15 \\
\hline & 04 & 03 & 03 & 04 & 03 & 17 \\
\hline & 03 & 02 & 02 & 03 & 02 & 12 \\
\hline & 03 & 02 & 02 & 01 & 01 & 09 \\
\hline Total & 13 & 10 & 10 & 11 & 09 & 53 \\
\hline \multirow[t]{4}{*}{ Text 9} & $02^{1 / 2}$ & 02 & $02^{1 / 2}$ & $02^{1 / 2}$ & $02^{1 / 2}$ & 12 \\
\hline & 04 & 03 & 03 & 02 & 02 & 14 \\
\hline & 03 & 02 & 02 & 03 & 03 & 13 \\
\hline & 04 & 02 & 03 & 01 & 02 & 12 \\
\hline Total & $13 \frac{1}{1} / 2$ & 09 & $10^{1 / 2}$ & $088^{1 / 2}$ & $09^{1 / 2}$ & 51 \\
\hline \multirow[t]{4}{*}{ Text 10} & $03^{1 / 2}$ & $02^{1 / 2}$ & 03 & 03 & 03 & 15 \\
\hline & 04 & 04 & 04 & 03 & 03 & 18 \\
\hline & 03 & 03 & 02 & 03 & 02 & 13 \\
\hline & 04 & 02 & 02 & 02 & 02 & 12 \\
\hline Total & $14^{1 / 2}$ & $11 \frac{1}{2}$ & 11 & 11 & 10 & 58 \\
\hline \multirow[t]{4}{*}{ Text 11} & $02^{1 / 2}$ & $02^{1 / 2}$ & $02^{1 / 2}$ & $02^{1 / 2}$ & 03 & 13 \\
\hline & 03 & 03 & 02 & 03 & 02 & 13 \\
\hline & 04 & 03 & 03 & 04 & 03 & 17 \\
\hline & 03 & 02 & 02 & 01 & 01 & 09 \\
\hline Total & $12^{1 / 2}$ & $101 / 2$ & $091 / 2$ & $10^{1 / 2}$ & 09 & 52 \\
\hline
\end{tabular}




\begin{tabular}{|c|c|c|c|c|c|c|}
\hline \multirow[t]{4}{*}{ Text 12} & $03^{1 / 2}$ & 03 & $03^{1 / 2}$ & $03^{1 / 2}$ & $03^{1 / 2}$ & 17 \\
\hline & 02 & 01 & 01 & 01 & 01 & 06 \\
\hline & 04 & 04 & 03 & 02 & 03 & 16 \\
\hline & 02 & 01 & $1 \frac{1}{2}$ & 01 & 02 & $05^{1 / 2}$ \\
\hline Total & $11^{1 / 2}$ & 09 & 09 & 07 & $09^{1 / 2}$ & 46 \\
\hline \multirow[t]{4}{*}{ Text 13} & 03 & 03 & 03 & $02 \frac{1}{2}$ & $02 \frac{1}{2}$ & 14 \\
\hline & 03 & 04 & 03 & 03 & 03 & 16 \\
\hline & 04 & 03 & 03 & 03 & 02 & 15 \\
\hline & 04 & 02 & 03 & 02 & 02 & 13 \\
\hline Total & 14 & 12 & 12 & $101 / 2$ & $091 / 2$ & 58 \\
\hline \multirow[t]{4}{*}{ Text 14} & 03 & 02 & 03 & 02 & 02 & 12 \\
\hline & 04 & 03 & 04 & 03 & 03 & 17 \\
\hline & 04 & 04 & 04 & 02 & 03 & 17 \\
\hline & 03 & 02 & 01 & 01 & 02 & 09 \\
\hline Total & 14 & 11 & 12 & 08 & 10 & 55 \\
\hline \multirow[t]{4}{*}{ Text 15} & $02^{1 / 2}$ & $02^{1 / 2}$ & 03 & 03 & 03 & 14 \\
\hline & 03 & 02 & 03 & 02 & 01 & 11 \\
\hline & 02 & 01 & 01 & 02 & 02 & 08 \\
\hline & 02 & 02 & 02 & 01 & 01 & 08 \\
\hline Total & $091 / 2$ & $071 / 2$ & 09 & 08 & 07 & 41 \\
\hline \multirow[t]{4}{*}{ Text 16} & $031 / 2$ & $03 \frac{1}{2}$ & $03^{1 / 2}$ & $02 \frac{1}{2}$ & $02 \frac{1}{2}$ & $12^{1 / 2}$ \\
\hline & 03 & 03 & 04 & 03 & 03 & 16 \\
\hline & 03 & 03 & 03 & 02 & 02 & 13 \\
\hline & 04 & 02 & 04 & 02 & 01 & 13 \\
\hline Total & $131 / 2$ & $11 \frac{1}{2}$ & $14 \frac{1}{2}$ & $091 / 2$ & $081 / 2$ & $571 / 2$ \\
\hline \multirow[t]{4}{*}{ Text 17} & 03 & $02^{1 / 2}$ & $02 \frac{1}{2}$ & $02^{1 / 2}$ & $02 \frac{1}{2}$ & 13 \\
\hline & 02 & 01 & 01 & 01 & 01 & 07 \\
\hline & 02 & 01 & 02 & 01 & 02 & 08 \\
\hline & 03 & 02 & 01 & 02 & 01 & 09 \\
\hline Total & 10 & $06^{1 / 2}$ & $06^{1} 1 / 2$ & $061 / 2$ & $06^{1} 1 / 2$ & 36 \\
\hline \multirow[t]{4}{*}{ Text 18} & 02 & 02 & 02 & 02 & 02 & 10 \\
\hline & 02 & 01 & 01 & 02 & 01 & 07 \\
\hline & 03 & 02 & 02 & 03 & 03 & 11 \\
\hline & 02 & 01 & 02 & 01 & 01 & 07 \\
\hline Total & 09 & 06 & 07 & 07 & 06 & 35 \\
\hline \multirow[t]{4}{*}{ Text 19} & 03 & 03 & 03 & $02 \frac{1}{2}$ & $02 \frac{1}{2}$ & 14 \\
\hline & 02 & 02 & 03 & 02 & 02 & 11 \\
\hline & 03 & 03 & 03 & 02 & 02 & 13 \\
\hline & 04 & 02 & 03 & 01 & 02 & 12 \\
\hline Total & 12 & 10 & 12 & $071 / 2$ & $08^{1} 1 / 2$ & 50 \\
\hline \multirow[t]{4}{*}{ Text 20} & 03 & 03 & 03 & 03 & 03 & 15 \\
\hline & 04 & 03 & 03 & 04 & 04 & 18 \\
\hline & 03 & 03 & 04 & 03 & 03 & 16 \\
\hline & 04 & 04 & 04 & 02 & 02 & 16 \\
\hline Total & 14 & 13 & 14 & 12 & 12 & 55 \\
\hline Text 21 & 03 & 02 & $02^{1 / 2}$ & $02^{1 / 2}$ & 03 & 13 \\
\hline \multirow[t]{4}{*}{ Total } & 04 & 04 & 03 & 03 & 04 & 18 \\
\hline & 03 & 02 & 02 & 02 & 02 & 11 \\
\hline & 04 & 02 & $03^{1 / 2}$ & 02 & 02 & $13^{1 / 2}$ \\
\hline & 14 & 10 & 11 & $09^{1 / 2}$ & 11 & $551 / 2$ \\
\hline \multirow[t]{4}{*}{ Text 22} & 03 & $02^{1 / 2}$ & $02 \frac{1}{2}$ & 03 & 03 & 14 \\
\hline & 03 & 03 & 02 & 03 & 03 & 14 \\
\hline & 03 & 02 & 02 & 04 & 03 & 14 \\
\hline & 03 & 02 & 02 & 01 & 02 & 10 \\
\hline Total & 12 & $091 / 2$ & $081 / 2$ & 11 & 11 & 52 \\
\hline \multirow[t]{4}{*}{ Text 23} & $02^{1 / 2}$ & $02 \frac{1}{2}$ & 02 & $02 \frac{1}{2}$ & $02 \frac{1}{2}$ & 12 \\
\hline & 02 & 01 & 01 & 01 & 01 & 06 \\
\hline & 04 & 04 & 03 & 02 & 03 & 16 \\
\hline & 02 & 01 & $02 \frac{1}{2}$ & 01 & 01 & $071 / 2$ \\
\hline Total & $101 / 2$ & $08^{1} 1 / 2$ & $081 / 2$ & $06^{1} 1 / 2$ & $071 / 2$ & $471 / 2$ \\
\hline \multirow{4}{*}{ Text 24} & $01 \frac{1}{2}$ & $01 \frac{1}{2}$ & 02 & 02 & 02 & 09 \\
\hline & 03 & 03 & 02 & 03 & 03 & 14 \\
\hline & 04 & 03 & 04 & 02 & 01 & 14 \\
\hline & 02 & 01 & 02 & 01 & 01 & 07 \\
\hline Total & $101 / 2$ & $08^{1 / 2}$ & 10 & 08 & 07 & 44 \\
\hline
\end{tabular}


Table 3. Summary of scores by success rate

\begin{tabular}{llll}
\hline Text & Total raw marks & Average & Percentage \\
\hline Text 13 & 58 & 58 & $58 \%$ \\
Text 10 & 58 & 58 & $58 \%$ \\
Text 16 & $57^{1 / 2}$ & $57^{1 / 2}$ & $571 / 2 \%$ \\
Text 2 & 56 & 56 & $56 \%$ \\
Text 4 & $55^{1 / 2}$ & $55^{1 / 2}$ & $551 / 2 \%$ \\
Text 21 & $55^{1 / 2}$ & $55^{1 / 2}$ & $551 / 2 \%$ \\
Text 14 & 55 & 55 & $55 \%$ \\
Text 20 & 55 & 55 & $55 \%$ \\
Text 8 & 53 & 53 & $53 \%$ \\
Text 11 & 52 & 52 & $52 \%$ \\
Text 22 & 52 & 52 & $52 \%$ \\
Text 9 & 51 & 51 & $51 \%$ \\
Text 19 & 50 & 50 & $50 \%$ \\
Text 23 & $47^{1} / 2$ & $47^{1 / 2}$ & $471 / 2 \%$ \\
Text 12 & 46 & 46 & $46 \%$ \\
Text 24 & 44 & 44 & $44 \%$ \\
Text 1 & 43 & 43 & $43 \%$ \\
Text 7 & 42 & 42 & $42 \%$ \\
Text 15 & 41 & 41 & $41 \%$ \\
Text 5 & 39 & 39 & $39 \%$ \\
Text 6 & $38^{1 / 2}$ & $381 / 2$ & $381 / 2 \%$ \\
Text 17 & 36 & 36 & $36 \%$ \\
Text 18 & 35 & 35 & $35 \%$ \\
Text 3 & $30^{1 / 2}$ & $301 / 2$ & $301 / 2 \%$ \\
\hline
\end{tabular}

\section{Copyrights}

Copyright for this article is retained by the author, with first publication rights granted to the journal.

This is an open-access article distributed under the terms and conditions of the Creative Commons Attribution license (http://creativecommons.org/licenses/by/4.0/). 